\title{
PEMBERDAYAAN KELUARGA MELALUI USAHA EKONOMI MIKRO
}

\author{
Fatwa Nurul Hakim ${ }^{1}$ \\ Balai Besar Penelitian dan Pengembangan Pelayanan Kesejahteraan Sosial \\ (B2P3KS). Kementerian Sosial RI
}

\begin{abstract}
This research aims to know about Kreasindo handicraft activities in the village of Tamantirto Village, Kasihan Subdistrict - Bantul, Yogyakarta, Indonesia. Bantul which produces bags and shirts that are mostly done by rural women, how much results or wages gained, and the utilization of income for families. The research was conducted using a qualitative descriptive method. Data collection techniques Observation and in-depth interview were used for data collection and an interview of 18 craftsmen and entrepreneurs as a craft manager. Of the 18 workers consisting of 15 female workers and 3 male workers. All come from the countryside with ELEMENTARY, JSS and high school backgrounds. For 18 workers who have been families, their children have entered education at the elementary school so that after carrying out homework, they have free time that can be utilized to work. Income gained to improve family welfare. While 3 male workers earned income is only enough to be used to meet the basic needs of families. Nevertheless, the work activity is maintained because it has no other job opportunities that can be used as a source of income. As for women workers in filling their free time want to work to increase family income.
\end{abstract}

Keywords : Craftsmen, Family Welfare, Kreasindo

\begin{abstract}
Abstrak
Penelitian ini bertujuan untuk mengetahui perkembangan usaha kerajinan tas dan kaos Kreasindo, serta dampak sosial bagi para pekerja/pengrajin dalam memanfaatkan upah atau penghasilan yang diperoleh serta dampak kesejahteraan bagi keluarganya. Penelitian dilaksanakan secara deskriptif kualitatif. Teknik pengumpulan data dilaksanakan secara observasi dan wawancara terhadap 18 pengrajin serta pengusaha sebagai pengelola kerajinan. Dari 18 pekerja yang terdiri dari 15 pekerja wanita dan 3 pekerja laki-laki berasal dari pedesaan dengan latar belakang SD, SLTP dan SMA. Bagi 15 pekerja wanita yang sudah berkeluarga, anak mereka sudah memasuki pendidikan di tingkat SD sehingga setelah melaksanakan pekerjaan rumah, mereka mempunyai waktu luang yang dapat dimanfaatkan untuk bekerja. Penghasilan yang diperoleh untuk meningkatkan kesejahteraan keluarga. Sedangkan 3 pekerja laki-laki penghasilan yang diperoleh hanya cukup digunakan untuk mencukupi kebutuhan pokok keluarga. Walau demikian kegiatan kerja tersebut tetap dipertahankan karena belum mempunyai peluang kerja lain yang dapat dijadikan sebagai sumber penghasilan. Sedangkan bagi pekerja wanita dalam mengisi waktu luang mereka ingin bekerja untuk menambah penghasilan keluarga.
\end{abstract}

Kata Kunci : Pengrajin, Kesejahteraan Keluarga, Kreasindo

\footnotetext{
${ }^{1}$ hakim.fatwa@yahoo.com
} 


\section{Pendahuluan}

Meningkatnya angka pengangguran di Daerah Istimewa Yogyakarta dari tahun ke tahun selalu berdampak sosial khususnya menyangkut kesejahteraan keluarga. Jumlah angka pengangguran di DIY pada 2018 mengalami peningkatan dibandingkan dengan 2017. Jika pada tahun 2017 jumlah pengangguran tercatat sebanyak 63.719 orang, maka pada tahun 2018 meningkat menjadi 73.350 orang (BPS 2018)

Hal tersebut terlihat dalam satu keluarga yang mempunyai anggota keluarga minimal lulusan SLTP ataupun SLTA bahkan perguruan tinggi yang idealnya masuk usia kerja. Namun jumlah peluang kerja tidak seimbang dengan jumlah tenaga kerja sehingga menimbulkan bartambahnya angka pengangguran. Kadangkadang terlihat ada peluang-peluang kerja dalam berbagai jenis, namun tidak semua tenaga kerja mau dan mampu menerima pekerjaan yang tidak sesuai dengan ideal/cita-citanya. Mereka memilih menjadi pengangguran dari pada bekerja tetapi tidak sesuai dengan tingkat pendidikan yang dimiliki. Hal demikian memicu bertambahnya permasalahan sosial khususnya dalam keluarga. Tingkat pemenuhan kebutuhan yang tidak seimbang dengan sumber daya ekonomi keluarga, akan menimbulkan rendah/turunnya kesejahteraan keluarga, yakni kurang dapat terpenuhinya kebutuhan keluarga baik secara fisik, ekonomi dan sosial. Hidup sederhana, mau menerima kenyataan yang ada akan membuat kehidupan tenang dalam keluarga, namun bukan berarti kita hanya menerima apa adanya. Manusia wajib berusaha sebatas kemampuan yang dimiliki. Pepatah menyatakan hidup adalah perjuangan untuk mencapai tujuan. Selagi badan ini sehat, kita harus mau bekerja sebatas kemampuan yang dimiliki.

Di Desa Tamantirto Kasihan Bantul Yogyakarta, di pedalaman kampung yang letaknya di daerah ledok/pinggiran sungai terdapat usaha kerajinan kecil yakni dengan produksi berupa tas dan kaos. Bentuk tas yang diproduksi adalah bermacammacam sesuai dengan pesanan. Ada tas sekolah, tas bekerja dan pakaian berbentuk kaos dalam sistem konveksi. Melihat kegiatan pembuatan tas dan kaos yang hasilnya cukup kuat, rapi dan berkualitas, maka banyak masyarakat yang tertarik dan berminat memesan tas atau kaos baik untuk souvenir ataupun kegiatan 
kelompok, bahkan dijadikan sebagai barang dagangan. Produksi tersebut dikerjakan oleh tenaga-tenaga wanita yang berasal dari daerah pedesaan Bantul, Sleman, Godean. Mereka terlihat dengan tekun mengerjakan pekerjaan yang kadang disertai senda gurau untuk menghilangkan rasa jenuh. Pekerja perajin tas dan kaos Kreasindo yang berjumlah 30 orang dan sebagian besar wanita (18 orang), dilihat dari usia sebagian besar sudah berumur di atas 30 tahun, namun mereka terlihat cukup mahir dan pengalaman dalam bekerja. Contohnya saat menjahit yang terlihat sangat rumit tapi karena terbiasa bekerja dengan cekatan, terampil.

Penduduk miskin di DIY, paling banyak terdapat di daerah perkotaan. Pada Maret 2019, jumlah penduduk miskin di wilayah perkotaan DIY tercatat sebanyak 304.660 orang atau lebih dua kali lipat jumlah penduduk miskin di daerah perdesaan yang banyaknya 143.810 orang. Meskipun demikian, persentase jumlah penduduk miskin di perdesaan lebih banyak dibandingkan di perkotaan yang mencapai 13,89 persen. Sedangkan penduduk miskin di perkotaan sebanyak 10,89 persen. Selama periode Maret 2018 - Maret 2019, jumlah dan persentase penduduk miskin di wilayah perkotaan menunjukkan fluktuasi. Pada Maret 2018, jumlah penduduk miskin perkotaan tercatat sebanyak 305.240 orang. Selanjutnya, pada September 2018 turun sebesar 2,22 persen atau menjadi 298.470 orang. Namun, pada Maret 2019, jumlah penduduk miskin kembali meningkat menjadi 304.660 atau terjadi kenaikan sebesar 6,2 persen. Menurut Hasibuan (1997), secara umum kemiskinan banyak terdapat di pedesaan. Masyarakat perkotaan lebih banyak memiliki kesempatan untuk mencari penghasilan di sektor informal, sehingga dapat meningkatkan kemampuan ekonomi keluarga. Sedangkan keterbatasan sektor informal di wilayah pedesaan tidak dapat membuka kesempatan bekerja bagi masyarakat pedesaan yang tidak dapat menambah penghasilan dan terkait dengan terbatasnya aset ekonomi yang dimiliki oleh masyarakat petani. Hal tersebut memicu terjadinya urbanisasi, larinya masyarakat desa ke kota guna mencari pekerjaan yang dapat menghasilkan. 
Masyarakat pedesaan yang sebagian besar $(60 \%)$ bekerja di sektor pertanian, namun hanya sebagai petani gurem (buruh tani). Dua pertiga garapan pertanian sebagai hasil yang diperoleh, namun besarnya penghasilan yang diperoleh cukup digunakan untuk memenuhi kebutuhan pokok keluarga yakni makan. Sedangkan kebutuhan pokok lainnya tidak dapat tercukupi, misalnya kesehatan, pendidikan, sosial dan lain-lain. Sehingga agar minimum dapat hidup secara layak perlu mencari tambahan penghasilan di luar pertanian.

Motivasi dalam upaya pemberdayaan keluarga sebagaimana ditulis Udiyati (2011:14), motivasi merupakan satu penggerak dalam hati seseorang untuk melakukan atau mencapai suatu tujuan. Motivasi adalah suatu proses untuk tercapainya suatu tujuan, seseorang yang mempunyai motivasi kecil berarti mempunyai kekuatan untuk tercapainya tujuan. Menurut Maslow dalam teorinya mengatakan bahwa kebutuhan pokok merupakan dasar pokok untuk mencapai tujuan. Kebutuhan pokok merupakan kebutuhan dasar yang harus terpenuhi.

Konsep motivasi yang dikemukakan beberapa ahli tersebut dapat menunjang keberhasilan tujuan pemberdayaan keluarga yang meningkatkan kondisi sosial keluarga yang dilihat dari indikator keberfungsian keluarga dan kemampuan keluarga dalam menjalankan peran dan fungsi keluarga. Pemberdayaan keluarga dilaksanakan dengan pemberian bimbingan sosial, keterampilan yang dapat menghasilkan produk yang laku dijual dan bagi pengrajin akan mendapatkan imbalan upah atau penghasilan. Dengan penghasilan yang diperoleh dalam menambah sumber ekonomi keluarga yang dapat digunakan untuk mencukupi kebutuhan keluarga. (Nana Syaodih Sukmadinata 2003:64)Sedangkan ciri-ciri lain sektor informal yang mudah dimasuki tenaga kerja, tidak membutuhkan pendidikan tinggi, kekerabatan tinggi, memberi peluang besar terhadap wanita yang mau bekerja karena wanita dipandang sebagai tenaga yang lebih luwes dan mau bekerja.

Hal tersebut dikuatkan oleh Rusdilah (1987) dalam Totok Mardikanto (1990:122) menyatakan wanita dominan di sektor informal baik di desamaupun di kota. Mereka terkonsentrasi dalam suatu aktivitas di sektor informal denganimbalan yang rendah. Dari dasar tersebut maka setiap usaha-usaha di sektor informal, pekerja banyak didominasi wanita. 


\section{Metode Penelitian}

Penelitian ini dilakukan pada Januari 2018, lokasi penelitian di desa Tamantirto, Kecamatan Kasihan Bantul. Alasan desa Tamantirto sebagai lokasi penelitian karena di desa tersebut banyak ditemukan usaha kecil rumahan yang produktif. Penelitian ini bersifat deskriptif kualitatif ingin mengetahui perkembangan usaha kerajinan tas dan kaos Kreasindo, serta dampak sosial bagi para pekerja/pengrajin dalam memanfaatkan upah atau penghasilan yang diperoleh serta dampak kesejahteraan bagi keluarganya. Teknik pemilihan informan dengan purposive sampling. Pengumpulan data dengan observasi dan wawancara terhadap dua orang selaku pengusaha dan 18 pekerja sebagai responden. Hal tersebut menarik perhatian untuk diadakan pengkajian lebih lanjut tentang: kegiatan para pengrajin, darimana asalnya, statusnya bagaimana, seberapa penghasilan yang diperoleh dan pemanfaatannya serta bagaimana kesejahteraan dalam keluarganya. Dengan menggunakan metode deskriptif kualitatif dan pendataan diperoleh dari wawancara secara mendalam, maka diperoleh informasi dari para pekerja di Kerajinan Kreasindo dan pemanfaatan penghasilan yang diperoleh dari pekerja Kreasindo serta dampak peningkatan kesejahteraan keluarga. Unit analisis penelitian ini adalah individu para pekerja di usaha kreasindo tersebut

\section{Hasil dan Pembahasan}

1. Sejarah Perkembangan Usaha

Kreasindo berdiri pada awal tahun 2005. Heri dan Mulyono memulai usahanya secara kecil-kecilan. Kedua orang ini menerapkan kemampuannya di bidang menjahit dengan mencoba membuat tas dan kaos yang kemudian dipasarkan ke berbagai daerah dan instansi pemerintah ataupun bank-bank swasta. Sedikit demi sedikit konsumen merasa tertarik dan mulai memesan, seperti Bank BPD yang pada waktu itu memesan sebanyak 25 biji. Karena merasa cocok dengan tas buatan Heri dan Mulyono mereka memesan lagi 50 buah tas untuk kantor. Mereka semakin bersemangat menekuni usahanya mengingat respon positif dari masyarakat terhadap hasil buatan mereka. 
Heri dan Mulyono memasarkan usahanya dengan cara "getok tular" dari orang ke orang sehingga pelanggan merekapun bertambah banyak. Karena jumlah pesanan yang semakin mengalir, mereka mulai kewalahan untuk mengelola produksi usaha sehingga mereka mulai mencari karyawan untuk membantu usahanya ini. Dari hasil penjualan produksinya pada tahun 2007 mereka bisa membeli mesin jahit untuk keperluan produksi sebanyak 7 buah dengan jumlah total karyawan 10 orang. Selain pemasaran di pulau Jawa mereka juga mulai merambah ke luar pulau Jawa seperti Samarinda, Kalimantan Timur. Salah satu pengalaman mereka yang masih diingat sampai sekarang adalah pesanan tas dari Riau yang mencapai 35.000 buah yang membuat mereka lembur berhari-hari demi mendapatkan kualitas sesuai dengan permintaan. Mereka tidak menyia-nyiakan kepercayaan pelanggan yakni dengan mengerjakan semua secara sungguh-sungguh dengan meminimalisir kerusakan pada produk mereka. Alhamdulillah hasil jerih payah mereka ini semakin mendapatkan respon yang baik tidak hanya pelanggan dari pulau Jawa saja tapi juga merambah sampai ke Nusa Tenggara.

Dalam waktu yang relatif singkat hasil usaha yang dirintis Heri dan Mulyono berkat ketekunannya sampai pada tahun 2008 terus meningkat. Pengadaan mesin jahit pun mulai ditambah menjadi 17 buah dan tenaga kerja mereka ada 18 wanita dan 12 pria. Mereka pun mulai mencoba kreativitas mereka untuk membuat payung dan hasilnya ternyata cukup bagus sehingga mulai menjadi produk yang diminati pelanggan.

Pada tahun 2010 ketika Yogyakarta dilanda bencana meletusnya gunung Merapi, Kreasindo sempat juga mendapat pesanan dari Jepang berupa jas hujan, payung, dan topi yang diperuntukkan bagi korban bencana merapi. Selain itu, pada tahun 2012 ada pesanan dari Papua berupa tas kantor. Sejak saat itulah usaha pembuatan tas makin berkembang sampai saat ini sehingga dapat memberi kesibukan pada karyawan.

Dengan mulai dikenalnya hasil produk kerajinan Kreasindo berupa tas dan kaos dengan bobot kualitasnya, maka selain melayani pesanan, juga memasarkan hasil produknya melalui toko-toko di Yogyakarta, Solo, Semarang, 
dan Surabaya. Harga yang diberikan pun tidak tinggi, namun cukup diperhitungkan dari harga bahan dasar, ongkos/upah untuk para pengrajin dan $25 \%$ bahan produk. Walaupun demikian, kualitas produknya juga selalu dipantau agar konsumen tidak kecewa dengan pembelian produk Kreasindo. Diharapkan dengan mempertahankan kualitas dan harga yang dapat dijangkau konsumen, maka semakin banyak pemakai produknya sehingga akan tetap mendapat pesanan dari instansi-instansi yang menggunakan dan toko-toko yang memasarkan. Dengan bertambahnya pesanan, maka dari pihak pengusaha dapat mengembangkan usahanya dan mengembangkan modal yang ada serta yang utama pihak majikan dapat mempekerjakan pekerjanya secara rutin. Sehingga tidak menjalani masa kekosongan/vakum dalam kegiatan usahanya. Sebab apabila terjadi kosongnya kegiatan tentu akan terjadi pengangguran khususnya bagi para pengrajin. Di sisi lain telah terjadi hubungan kekerabatan antara majikan dan pekerja, maka diupayakan agar usaha yang dilaksanakan dapat berjalan dengan lancar dan memberikan honor/upah bagi para pengrajin. Sebaliknnya bagi para pengrajin yang sebagian besar sudah berkeluarga dan mempunyai tanggungan anak, diharapkan kerajinan Kreasindo tetap lancar karena honor/upah yang diterima merupakan sumber penghasilan untuk kesejahteraan keluarga.

Bagi masyarakat lingkungan, dengan adanya kegiatan kerajinan Kreasindo, selain dapat menyemarakkan suasana lingkungan yang sebelumnya terlihat sepi menjadi ramai. Di sisi lain, pihak pengusaha cukup dapat beradaptasi dengan masyarakat lingkungan serta bersosialisasi dengan baik, sehingga dapat menunjang pembangunan masyarakat di lingkungannya.

2. Penyerapan Tenaga Kerja

Sampai tahun 2012 usaha kerajinan tas dan kaos Kreasindo masih terlihat eksis jumlah tenaga yang ada terhitung 30 tenaga yang terdiri dari 18 tenaga wanita dan 12 tenaga laki-laki. Dalam lokasi kerja dipisahkan 2 tempat yakni satu tempat ukuran 10 x 20 meter untuk kegiatan kerajinan tas dan satu tempat $8 \times 10$ meter untuk kerajinan kaos. Masing-masing dilengkapi dengan mesin jahit, 8 mesin untuk menjahit tas dan 6 mesin jahit untuk menjahit kaos 
serta ruang terbuka yang digunakan sesuai kebutuhan antara lain kebutuhan memotong-motong bahan pembuatan tas, pengepakan dan penyimpanan, yang jelas ruang besar yang tersedia dimanfaatkan sesuai dengan kegiatan pekerjaan. Demikian pula di ruang kerajinan kaos.

\section{Daerah Asal Tenaga Kerja}

Tenaga kerja yang sebagian berasal dari lokasi pedesaan, mereka datang semula diajak temannya yang sudah bekerja di Kreasindo dengan secara "getok tular" tenaga tersebut datang sendiri tanpa memasang iklan. Menurut keterangan dari pengrajin yang bekerja sebagai penjahit, semula saat mereka datang tidak tahu apa yang harus dikerjakan. Namun dengan bimbingan dari teman-teman sehingga dalam waktu 3 bulan mereka sudah bisa menjahit tas ataupun kaos sesuai dengan pesanan yang ada. Dari 18 pekerja wanita, 14 diantaranya bekerja sebagai penjahit sesuai dengan mal/desain bahan yang telah ditata. Mereka terlihat dengan tekun dan hati-hati dalam bekerja. Sedangkan 4 orang diantaranya 2 orang bertugas sebagai pemotong bahan dan 2 orang sebagai perapi hasil bahan yang telah dijahit.

Pekerja laki-laki yang berjumlah 12 orang, 2 diantaranya juga sebagai pendesainer dan pemotong bahan dan 4 orang sebagai pekerja administrasi dan 2 orang sebagai pembelanja bahan yang lainnya sebagai pekerja pelengkap yang setiap saat setiap keluar masuk melengkapi usaha kerajinan.

4. Waktu Bekerja

Menurut hasil wawancara, mereka siap bekerja mulai jam 07.30 sampai jam 12.00. Mereka istirahat dengan mendapat jaminan makan siang satu kali yang diwujudkan uang Rp 5.000 dan makan di warung terdekat. Jam 13.00 mereka mulai bekerja kembali sampai jam 17.00. Jarak tempat tinggal dan tempat bekerja rata-rata $10-15 \mathrm{~km}$ yang dapat ditempuh setengah jam dengan menggunakan sepeda motor.

Pada saat istirahat, ada yang membeli makanan di warung terdekat. Sedangkan yang lain, mengingat pekerjaan yang harus cepat selesai, maka cukup menitipkan beli makanan dengan teman lainnya. Dengan demikian saat istirahat mereka tetap mengerjakan pekerjaan yang harus selesai. Selain itu, 
sebagian besar pekerja adalah beragama Islam, sehingga saat istirahat secara bergilir mereka melaksanakan ibadah sholat dhuhur. Dengan sistem kerja secara borongan, maka antarpekerja satu dengan lainnya saling mendukung cepat selesainya pekerjaan sesuai dengan target. Walau demikian, mereka tetap mempertahankan kualitas hasil kerajinan yang dikerjakan, sehingga tidak hanya semata-mata mengejar target yang harus dipenuhi, tapi kualitas hasil produksi tetap dipertahankan. Hal tersebut tidak lepas dari kontrol pengusaha/majikan walaupun hal tersebut dilaksanakan secara santai tapi pengawasan tetap ada.

Menurut hasil wawancara yang diperoleh bagi pekerja perempuan maupun laki-laki dengan padatnya waktu kerja mereka tetap merasakan semangat dalam melaksanakan kegiatan. Walau demikian, kegiatan kemasyarakatan/kekeluargaan antarsesama pekerja dan dengan majikanpun tetap berjalan baik dan penuh tenggang rasa. Sebagai contoh, saat saudara pekerja meninggal dunia, mereka bisa meminta ijin dengan majikan dan sesama pekerja. Pekerjaan merekapun bisa diselesaikan secara bersama. Hal tersebut berlaku juga saat teman lain mempunyai kepentingan yang tidak bisa ditinggalkan. Kekerabatan dan persuadaraan antara pekerja dan majikan terjalin dengan penuh keakraban. Demikian pula saat di lingkungan kerja terdapat tetangga yang meninggal, maka selain majikan, pekerjapun ikut melayat dengan waktu yang diatur/secara bergantian. Demikian saat di lingkungan tempat kerajinan terdapat hal-hal yang memerlukan bantuan, maka pihak majikan tidak tanggung-tanggung memberikan bantuan bagi masyarakat lingkungan.

Dengan padanya kegiatan kerja yang harus mengejar target (sesuai dengan pesanan) maka para pekerjpun dengan semangat mendukung kegiatan dengan tanpa rasa berat/keluh kesah. Sebab dengan tercapainya target maka berarti akan mempercepat pekerja untuk menerima upah bahkan lebih banyak produksi, upah yang diterima akan meningkat. Hal tersebut merupakan salah satu motivasi mereka dalam bekerja untuk selalu bersemangat mengerjakan tugas.

Selain itu dari pihak majikan pun dakan memberikan insentif sesuai dengan hasil produksi yang dikerjakan. Bahkan kadang-kadang saat banyak 
pesanan, maka pekerjapun mengerjakan pekerjaan dengan sistem lembur yakni membawa bahan yang sudah dipotong untuk dijahit/dikerjakan di rumah. Menurut pengalaman para pekerja, hal tersebut dilaksanakan dengan senang sebab dengan banyaknya produksi maka penghasilan yang diperoleh akan meningkat.

Menurut hasil wawancara dengan para pekerja baik laki-laki maupun perempuan, dengan jadwal kerja yang telah ditentukan mereka berusaha mentaati peraturan. Bagi pekerja perempuan yang juga sebagai ibu rumah tangga, mereka berusaha mengatur waktu dengan menyelesaikan pekerjaan rumah dan pekerjaan kerajinan. Memang pada saat tertentu mereka mempunyai keperluan untuk keluarga dan kemasyaratan. Contohnya saat melayat saudara/tetangga mereka harus ijin dengan majikan dan teman-teman sekerja, kemudian pekerjaannya pun digantikan teman lainnya. Demikian pula sebaliknya, saat teman lain ada keperluan merekapun ganti mengerjakan tugas teman yang sedang ada keperluan. Kekerabatan kerjasama sesama pengrajin telah terjalin secara kekeluargaan sehingga semua kegiatan tetap berjalan dengan lancar.

5. Umur dan Status Pekerja

Dari 30 pekerja, 13 diantaranya $(33,33 \%)$ berumur antara $20-30$ tahun, 16 berumur antara 30 - 40 tahun $(53,33 \%)$ dan satu orang lagi berumur 50 tahun bekerja sebagai penjaga dan pembersih ruangan. Secara status 26 pekerja sudah bekerja dan mempunyai tanggungan anak $1-2$ orang. Enam orang masih lajang dan satu orang berstatus duda. Dari 30 pekerja yang terdiri dari 18 wanita, sebagian besar (13 diantaranya) sudah berkeluarga dan 12 pekerja laki-laki (10 diantaranya sudah berkeluarga), satu orang, status duda dan satu orang belum menikah.

6. Jaminan Kerja

Bagi pengusahan Kreasindo, sebagai rasa tanggung jawab terhadap tenaga kerjanya maka dari 30 tenaga kerja yang ada, setelah satu tahun mereka mantap bekerja maka akan diangkat sebagai pekerja tetap. Untuk menjaga dan mengantisipasi terjadinya gangguan kesehatan, khususnya kecelakaan saat 
mereka bekerja, maka semua pekerja diasuransikan oleh pengusaha di lembaga Asuransi Bumi Asih dengan pembiayaan publik setiap tahun. Namun selama waktu 10 tahun pekerja diasuransikan, belum pernah pekerja yang mengalami kecelakaan pada saat kegiatan kerja.

Dengan adanya jaminan asuransi yang juga diketahui oleh para pekerja, maka menimbulkan rasa senang dan semangat bekerja. Asuransi tersebut berupa asuransi kecelakaan kerja dan kematian. Walau hal tersebut tidak diinginkan/ diharapkan para pekerja, namun dengan adanya jaminan asuransi kerja berupa santunan kecelakaan dan kematian, maka mereka merasakan nyaman dalam melaksanakan pekerjaan. Demikian pula dengan adanya jaminan asuransi kecelakaan kerja dan kematian bagi pengusaha akan mengurangi beban/material saat pekerja mengalami kecelakaan dan kematian. Namun selama ini dari tahun 2005 sampai 2012 berjalan, belum pernah terjadi kecelakaan dan kematian bagi para pekerja.

7. Tingkat Pendidikan

Dari 30 orang, 2 orang berpendidikan S1, 5 orang berpendidikan SMU/ 1 orang SMEA, 18 orang SLTP dan 5 orang pendidikan SD.

Tabel 1

Tingkat Pendidikan dan Pekerjaan

\begin{tabular}{|c|l|c|c|c|}
\hline No & \multicolumn{1}{|c|}{ Pendidikan } & Jumlah & Pekerjaan & Jumlah \\
\hline 1 & S1 & 1 & Administrasi dan pemasaran & 3 \\
& & & Desain & 2 \\
2 & SMU/SMEA & 8 & Penjahit tas & 12 \\
3 & SLTP & 16 & Penjahit kaos & 6 \\
4 & SD & 5 & Pengrajin & 6 \\
& & 30 & Pembersih & 1 \\
\hline & Jumlah & & 30 \\
\hline
\end{tabular}

Sumber: Data Primer Kreasindo 2018 
Dilihat dari latar belakang pendidikan pekerja di kerajinan Kreasindo dari 30 pekerja, satu orang berpendidikan S1 yang kebetulan dari fakultas ekonomi akuntansi sehingga ditugaskan dalam administrasi bagian keuangan dapat mengklasifikasi keuangan antara pemasukan dan pengeluaran. Namun dalam kebijakan dan putusan tetap kewenangan pengusaha sebagai manajer.

Sedangkan pekerja administrasi lainnya 2 orang orang terdiri dari pendidikan SMA dan SMEA yang masing-masing membantu kegiatan administrasi. 26 pekerja lainnya melaksanakan pekerjaan kerajinan sesuai dengan fungsi atau pekerjaan masing-masing, sebagai pendesain, penjahit dan pengrajin.

Dilihat dari latar belakang pendidikan, 7 orang berpendidikan SMU, satu orang SMEA/SMK, 18 orang (60 persen) dari pendidikan SLTP. Menurut pengakuannya 6 orang diantaranya pernah mengikuti kursus menjahit namun selanjutnya dikembangkan di kerajinan Kreasindo baik untuk menjahit tas maupun kaos. Sedangkan penjahit lainnya, mereka tidak pernah mengikuti kursus. Mereka kerja belajar bersama teman sesama pekerja di Kreasindo. Dengan kesabaran dan ketelatenan, mereka bisa melaksanakan kegiatan jahit. Bagi 2 orang pendesain menurut pernyataannya, mereka mempunyai latar belakang pendidikan SMA. Sedangkan keterampilan mendesain diperoleh dari pengalaman dan pembelajaran dari lingkungan saja dan hasilnya cukup mumpuni dalam setiap mendesain sesuai dengan pesanan yang ada, dan 6 orang sebagai pengrajin dan penata barang baik dari proses pembuatan maupun pengepakan barang yang akan dikirim.

\section{Penghasilan Pekerja}

Dari 30 orang, masing-masing mempunyai penghasilan yang tidak sama sesuai dengan kemampuan dan jenis pekerjaan yang dilakukan, sistem borongan yakni pekerjaan dikerjakan secara bersama untuk memenuhi target yang ditentukan. Mereka menerima penghasilan sesuai dengan profesinya masing-masing sebagaimana pada tabel berikut. 
Tabel 2

Penghasilan pekerja per minggu

\begin{tabular}{|c|l|c|c|c|}
\hline No & \multicolumn{1}{|c|}{ Pekerjaan } & $\begin{array}{c}\text { Umur } \\
\text { (tahun) }\end{array}$ & Jumlah & Hasil/minggu \\
\hline 1 & Pembersih & 40 & 1 & Rp 200.000 \\
2 & Pengrajin & $20-30$ & 6 & Rp 300.000 \\
3 & Penjahit & $20-35$ & 17 & $\operatorname{Rp~} 400.000$ \\
4 & Desain & $20-25$ & 2 & $\operatorname{Rp~} 450.000$ \\
5 & Administrasi & $20-40$ & 4 & $\operatorname{Rp~} 300.000$ \\
\hline
\end{tabular}

Sumber: data primer Kreasindo 2018

Dari perolehan penghasilan pengrajin yang diterima setiap minggu atau tepatnya pada hari Sabtu. Secara rinci dapat kita hitung misalnya untuk pekerja pembersih yang setiap minggu menerima honor/upah Rp 200.000. Satu bulan mereka menerima Rp 800.000. Dilihat dari penghasilan yang diterima memang lebih rendah dibanding UMR di Yogyakarta. Namun kegiatan pembersih hanya dilaksanakan setiap pagi (sebelum karyawan datang dan setelah karyawan pergi). Sedangkan waktu-waktu luang mereka dapat melaksanakan pekerjaan lain di luar kerajinan, sehingga selain menerima upah/honor dari Kreasindo, juga mempunyai penghasilan lain walau sifatnya serabutan/insidental. Menurut hasil wawancara yang diperoleh dengan penghasilan yang ada dan penghasilan di luar cukup dimanfaatkan untuk menghidupi dirinya yang berstatus duda. Kebetulan rumah/tempat tinggal pembersih juga berdampingan dengan kegiatan kerajinan bahkan dia juga berfungsi sebagai penjaga rumah kerajinan bersama pengusaha.

Sedangkan penghasilan lainnya dari pengrajin penjahit, pendesain dan bagian administrasi apabila dihitung perbulan masing-masing di atas UMR di Yogyakarta (sampai bulan Mei 2012 Rp 1.065.000,-/bulan). Menurut pernyataan masing-masing pekerja, honor tersebut kadang-kadang ada insentif sesuai dengan jumlah produk kerajinan sehingga mereka tetap giat melaksanakan pekerjaan dan menurut pengakuannya. Mereka tetap mantep 
bekerja di kerajinan Kreasindo walau honornya tidak tinggi, namun merupakan kegiatan tetap yang dapat diharapkan untuk mencukupi kebutuhan keluarga.

9. Pemanfaatan Penghasilan

Dari hasil wawancara menunjukkan bahwa 1 orang bekerja sebagai pembersih berstatus duda, maka penghasilannya hanya dimanfaatkan untuk memenuhi kebutuhan hidup sendiri. Sementara 17 orang wanita, terdiri dari 6 orang sebagai pengrajin penata hasil produksi dan 11 orang penjahit, penghasilan yang diperolehnya digunakan untuk memenuhi kebutuhan keluarga, walaupun kebutuhan pokok sudah dipenuhi suami. Demikian pula 2 orang bekerja di bidang desain mempunyai tanggung jawab untuk memenuhi kebutuhan keluarga. Bagian administrasi sebanyak 4 orang sudah berkeluarga penghasilan yang diperoleh untuk memenuhi kebutuhan keluarga.

Dengan bertambahnya penghasilan dari usaha kerajinan Kreasindo menurut pengakuan para pekerja khususnya ibu-ibu dapat menambah kesejahteraan keluarga. Penghasilan yang diperoleh dari suami rata-rata bekerja di sektor informal cukup dipakai untuk memenuhi kebutuhan pokok. Namun dengan tambahan penghasilan yang diperoleh dapat dimanfaatkan untuk memenuhi kebutuhan diri, anak dan sosial di lingkungannya sehingga tingkat kesejahteraan keluarga meningkat.

10. Bekerja sebagai Pengisi Waktu Luang

Dari 18 pekerja wanita kerajinan Kreasindo, yang semuanya berasal dari daerah pedesaan, menurut pengakuannya pada saat suami bekerja, anakanak sekolah, mereka mempunyai waktu luang dan ingin bekerja. Dengan adanya informasi dari saudara atau tetangga bahwa dibutuhkan tenaga kerja untuk bekerja di kerajinan Kreasindo, maka mau bekerja untuk mengisi waktu dan dapat menambah penghasilan. Pada awal bekerja, mereka mau melaksanakan pekerjaan apapun sebagai pelengkap tenaga yang dibutuhkan, bagi yang mempunyai keterampilan menjahit mereka mulai mencoba pekerjaan jahit tas atau kaos, ternyata karena biasa mereka senang melakukan kegiatan kerjanya. Hal tersebtu didukung adanya penghasilan yang diperoleh yang biasanya cukup untuk memenuhi kebutuhan keluarga. Sementara bagi mereka 
yang mempunyai tanggungan anak, saat mereka bekerja maka anak dititipkan pada orangtua atau dilatih untuk mandiri sambil menunggu orangtua pulang bekerja.

Kerajinan tas dan kaos Kreasindo merupakan salah satu pembuka peluang kerja di sektor informal yang sejak berdirinya usaha kerajinan Kreasindo dengan proses perkembangannya selama delapan tahun tetap bertahan dengan hasil produksi tas dan kaos sesuai dengan pesanan. Dengan lancarnya hasil produksi yang terbukti, selalu adanya pesanan baik untuk daerah Yogyakarta maupun dari luar Yogyakarta, menunjukkan bahwa kegiatan kerajinan tetap berjalan sehingga bagi para buruh atau pekerja tetap mendapat kegiatan kerja yang menyangkut upah atau penghasilan yang diterima.

Munculnya kegiatan di sektor informal adalah karena terbatasnya kapasitas industri-industri formal dalam menyerap tenaga kerja yang ada sehingga terdapat kecenderungan bahwa sektor informal banyak muncul di pinggiran-pinggiran kota besar. Anggapan lain juga menyatakan usaha sektor informal sudah lama ada, khususnya dalam usaha ekonomi secara tradisional (Anney Fredy, 2003:7).

Adapun ciri-ciri yang menonjol di sektor informal adalah jumlah barang sedikit, bermutu rendah, modal sangat terbatas, teknik masih tradisional, kesempatan kerja elastis. Menurut Santos (dalam Anney, 2004:8), sektor informal dipandang sebagai usaha tradisional yang mandiri yang ketergantungannya terhadap faktor-faktor luar sangat kecil dan cenderung memanfaatkan tenaga kerja di kalangan keluarga terdekat (sistem relasi). Sedangkan bagi pengusaha laju dan mundurnya sangat tergantung pada keluwesan dalam mengakses hasil pemasaran usahanya.

Dalam hal kegiatan, kerja di sektor informal ada dua istilah antara buruh dan majikan. Majikan adalah pihak yang memiliki kewenangan dalam menentukan proses produksi, menentukan dan mengatur pembiayaan produksi, mempekerjakan pihak lain serta berkewajiban memberikan imbalan. Imbalan tersebut dapat berbentuk upah, fasilitas kerja yang memadahi, dan jaminan sosial. Sedangkan buruh bisa didefinisikan sebagai orang atau pihak yang mengikatkan diri untuk bekerja pada pihak tertentu dengan memperoleh imbalan. 
Relasi buruh majikan di sektor informal biasanya merupakan relasi kerja berdasarkan penggajian/kontrak tidak tertulis (lisan). Jenis kontrak seperti ini jelas dapat merugikan pihak yang memiliki posisi utama yang kontrak/buruh. Faktor yang terpenting bagi keadaan ini adalah surplus cadangan buruh dari kalangan "pengangguran" dan "setengah nganggur". Dalam kedudukan yang rawan bahwa banyak orang lain yang siap menggantikannya, buruh di berbagai sektor informal mau tak mau harus menerima kondisi kerja yang kurang memberikan jaminan ekonomi, apalagi jaminan sosial baginya.

Dalam hal hubungan kerja antara majikan dan buruh di kerajinan Kreasindo tidak dilaksanakan secara formal, namun yang terlihat adalah hubungan kekeluargaan dengan batas-batas tertentu. Majikan berusaha mengontrol hasil kerja para pengrajin dan pihak pengrajinpun berusaha bekerja dengan tertib sesuai dengan waktu kerja. Hubungan kekeluargaan itupun terlihat pada saat pengrajin mengalami masalah dalam keluarga. Misalnya ada anggota keluarga sakit, majikanpun berusaha mengunjungi dan memberikan bantuan bagi pengrajin. Hal tersebut menambah keakraban bagi majikan dan pengrajin dengan batas-batas tertentu. Sebaliknya bagi pihak pengrajin pun berusaha melaksanakan pekerjaan sebaik mungkin sesuai dengan kewajibannya.

Dengan pengisian waktu luang bagi pekerja wanita, adanya tambahan penghasilan akan menambah sumber penghasilan keluarga dan dapat dimanfaatkan untuk mencukupi kebutuhan lain sehingga dapat meningkatkan kesejahteraan keluarga. 


\section{Kesimpulan}

Wanita sebagai ibu rumah tangga akan selalu berupaya untuk bekerja sesuai dengan kemampuan yang dimiliki. Mereka tidak mau berpangku tangan di rumah dengan mengandalkan penghasilan kerja suami. Kerajinan Kreasindo membuka peluang bagi mereka yang mau dan mampu bekerja dengan hasil produksi tas dan kaos. Sebagian besar pekerja yang terdiri dari ibu-ibu rumah tangga (wanita pedesaan) yang sebagian besar sudah berkeluarga dan mempunyai tanggungan anak 1-2, mampu mendukung produksi kerajinan yang dapat dipasarkan di luar Jawa. Penghasilan yang diperoleh pengrajin digunakan untuk mencukupi kebutuhan sehari-hari minimal Rp 300.000/minggu, dapat dimanfaatkan untuk mencukupi kebutuhan keluarga. Sedangkan pekerja laki-laki dengan penghasilan yang ada dapat dimanfaatkan untuk memenuhi kebutuhan keluarga, meskipun masih paspasan. Namun demikian, untuk pola hidup sederhana di pedesaan cukup dimanfaatkan dalam memenuhi kebutuhan pokok bagi pekerja laki-laki, dan meningkatkan kesejahteraan keluarga bagi pengrajin wanita.

\section{Daftar Pustaka}

Friday, Anne, dkk. 2003. Hubungan Perburuhan di Sektor Informal: Permasalahan dan Prospek. Bandung: Yayasan Akatiga.

Departemen Sosial. 1995. Pedoman Teknis Pembinaan Kesejahteraan Anak Dalam Keluarga Pengganti. Jakarta.

Suharto, Edi, dkk. 2004. Kemiskinan dan Keberfungsian Sosial: Studi Kasus Rumah Tangga Miskin Indonesia. Bandung: STKS Press.

Suranto, Edi. 2009. Teori motivasi. http://catatankuliahdigital.blogspot.

Mardikanto, Totok. 1990. Wanita dan Keluarga. Surakarta: PT. Tritunggal.

Udiyati, Trilaksmi, dkk. 2011. Pemberdayaan Keluarga Miskin Potensial dalam Meningkatkan Kesejahteraan Keluarga. Yogyakarta: B2P3KS Press.

Listyaningsih, Umi. 2004. Dinamika Kemiskinan di Yogyakarta. Yogyakarta: Pusat Studi Kependudukan dan Kebijakan Universitas Gadjah Mada. 